\title{
総説
}

\section{Personal Reminiscence on Rheology}

\author{
by
}

Bun-ichi TAMAMUSH

(Nezu Chemical Institute, 1-26 Toyotamakami, Nerimaku, Tokyo 176)

\section{レオロジーに関する個人的回想}

\author{
玉 蟲 文 - *
}

（原稿受理：1978年 7 月24日）

\section{レオロジー研究の初まったころ}

レオロジー (rheology) といら名称は良く知られているよ5に, 初めてアメリカの物理化学者 E.C. Bingham (1879 1945) によ って提案され，1929年ワシントン (D.C.) に批るアメリカ・レ オロジ一学会の創立に際して正式に採用されたものである。この 名称に刘しては“物体と流動の科学”という注釈が加えられた。 上記学会は機関誌：Journal of Rheology を刊行したが，何 かの理由によって長続きせず，学会が American Institute of Physics に吸収されると其に(1933), 雑誌もJournal of Applied

Physics に合体された。しかし，Bingham の名はレオロジーの 父として国際的に今も記念されている。彼は1905年に学位 (Ph. D.) を受けると直にドイッの W. Ostwald の研究室に留学し， 翌年帰国してから液体の粘性率の絶対測定法の研究から進んで粘 土のサスペンジョンなどの流動性の研究に努力し，いわゆる“ど ンガム流動”の現象を登見し，レオロジーに打ける一つの礎石を 築いた。 その一連の研穵は著畵：Fluidity and Plasticity, New York（1922）として遺された.

上記のワシントンに怙けるアメリカ・レオロジ一学会の創立に はドイツの H. Freundlich, Wo. Ostwald, オランダの H.R. Kruyt, イスラェル（後年）のM. Reiner, イギリスのG.W. Scott Blair などが参画したと伝えられるから，ある意味ではレオロジ 一に打ける最初の国際的会合であったと考光られる。ちなみに, H. Freundlich はもともと W.Ostwald の下での助手・私講師で あったし，Wo. Ostwald はW. Ostwald の子息であったから， Bingham とは同門の間柄であり, M. Reiner は当時 Bingham の 下 (ラファイェット大学) で研究していたし， Scott Blair む当 時ロックフェラー奨学金によってアメリカに留学中であった。こ

* 根津化学研究所 東京都練馬区豊玉上 $1-26$ 武藏大学構内
のことを回顧すると、レオロジ一の起源が互いに国籍を異にしな がらも，同学同士の談合の中にあったと言うことができよう。

ところで筆者は1927〜1929年, ドイッ・ベルリンのカイザァウ イルヘルム協会 (K.W.G.) 飞属する物理化学一電気化学研究所 （現在マックス・プランク協会・フリッッ・ハーバー研究所）の Freundlich 研究室に捻いて, 界面化学々くに吸着の闆題に関する 研究に従事した。当時 Freundlich は所長 F. Haber の所長代理

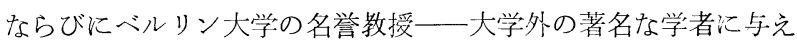
られた名称で物理学の Einstein も同栐の処遇であった一一重職 に在ったが，その研管室は 3 名の助手 (H. Locher, H. Kantsky, G. Ettisch の諸博士，いずれも著名な研究者で教授候補）と共に 給20名のドイツ国内・国外の研究者を包容し，第一次大戦後の物 資欠乏の際にあってもその研究活動は創造の意欲に満ちていた。 既に1920年代の前半に扮いて，この形呪室では数種の無機的・有 機的コロイド系 (ゾル括よびゲル) に执いて, 流動弾性 (Fliesselastizität), チキソトロピー(Thixotropie), 流動複屈折・二色性 (Strömungsdoppelbrechung・dichroism) と名付けられよらな現 象の登見が行われて扣り, 筆者の滞在中もそれらの㼋究が続けら れていた。これらの現象の研密は明らか沈レオロジ一の発展に括 ける先駆的役割を果たしたものである。これら研究の詳細につい ては本文末尾に記した文献に譲ることにし, 筆者がこの研究室に 捻いて見聞したことや直接に接触した研究者たちの印象について 記すことにしたい，何よりも注目すべきことはこれらの研究と発 見が極めて簡単な器具と単純な実験技術によって遂行されたとい ら事実である。

この研究室は研究所の二階の大部分を占めていたが，教授就よ び助手の個室とそれに付属する 小研究室のほかに二つの大部屋 があり，若い研究者・研究生はそこにそれぞれ局限された場所 （Sitz）を与えられていた，筆者の属した部屋にはドクター候補 
の G. Lindau, K. Zöllner, F. Juliusburger（いずれもドイツま たはオーストリー人)のほか，アメリカからの H. A. Abramson (ロックフェラー研究所), L.H. Reyerson (ミネソタ大学) などが いた，筆者は隣接の場所にいた前記 3 人ととくに親しくなり，実 験の合間に括しゃべりをした。. K. Zöllner（後にアメリカに移住， Sollner と改名した）は $\mathrm{Fe}_{2} \mathrm{O}_{3}$-ゾル， $\mathrm{V}_{2} \mathrm{O}_{5}$-ゾルのチキソトロピ 一について固化時間の測定, $\mathrm{H}^{+}$その他のイオンの影響などにつ いて調べていたが，巨大な体格の持主で大きな手で小さい試験管 に封じたサンプルを振る彼の姿は今も眼に浮ぶ. Lindau は $\mathrm{Fe}_{2} \mathrm{O}_{3}$ ーゾルの凝結以対する血清アルブミンの増感作用を調べ，その結 果を生体中に抢けるバクテリアの抗体による凝集のメカニズムと 関係付けた. その後, 彼は $\mathrm{F}$-教授との連名でアメリカ産ベントナ イト・サスペンションについてのチキソトロピー拈よび関連現象 の研究の諭文を㓥いたが，その別刷が帰国後の筆者に扣くられて きたのは1932年であった．Zocher とその協力者はコロイド光学 的研究を続行していたが $\mathrm{V}_{2} \mathrm{O}_{5}$-ゾルに扣けるタクトイドの形成, $\mathrm{Fe}_{2} \mathrm{O}_{3}$-ゾルに打けるシラ一層の形成，中間相（液晶）などの問題 についての新知見を寄与した。これらはいずれもレオロジーに関 係ある研究であるが，F-教授の矿窏室で第一次大戦後ナチスの 政権獲得に至る約15年間に行われたコロイド・界面化学およびレ オロジーに関する研㠰はとの独創性に打いて比類少ないものと言 ってよかろう。

K. Weissenberg の名は今もな招広くレオロジ一研究者の間で 知られているが，彼は当時A. Einsteinの指導下にあった K.W.G. の理諭物理学研究所に属していた，元来は幾何学を専攻したとい う彼であったが，後に記すような動機から，物理化学者との接触 をもつようになり，しばしば私たちの研究所を訪れ，Freundlich 研究室や Polanyi 研管室の人々に接触し, その知見を通じて彼自 身の独自の道を拓きつつあった。筆者は彼が親密な仲であった Zocher と研究所内の廊下を往来しながら話し合っている姿を見 た．彼が粘弾性体について理論的考察を進め，やがては彼の名を 付したレオゴニオメーターを製作するに至ったのは，このような 自由な交遊から生まれたものと考兄られる，彼が同じくその名を 付したX-線カメラを考案したのは，Polanyi 教授とその門下の人 々との交遊によるものであった。 このように専門を異にする研究 者間の談話・討論を陰ながら奖励したのは所長 Haberであった。 彼こそは科学研究に扣ける各個人の特質に忘じてその才能を引き 出す天才的指導者であった。

Haber-Freundlich-Polanyi の名によって代表された K.W.I. 物 理化学研究所に扣ける当時の研究活動は当時世界の物理化学の一 大焦点と見做されたが，1933年ナチス政権が確立するに及んで， この研究所は多数のユダヤ系また他国の研究者を包容していたた めに人的に壊滅状態になった. Freundlichはロンドン大学・ユニ ヴァシティ・カレッジの G. Donnan 教授の招きによってそこに 約 5 年 (1933〜38) 滞在したが，その間にベルリン以来の協力者 Juliusburger 抢よび Sollner と共に主としてレオロジーに関連 する問題の研究を進めた。例㓪ば，イギリスの流体力学者 $\mathrm{O}$. Reynolds によって名付けられたダイラタンシー (dilatancy) と チキソトロピーとの関係について，スレート質鉱石から作られる 化石の成因について，ゲルの構造と超音波の影響など。また， Juliusburger は新しい共同研究者 Pirquet と共にレオロペクシー (rheopexy) の現象を発見した (1936)。この間に Freundlich は
“Thixotropy” (Paris, 1935) のモノグラフを刊行し，筆者にもそ の一本を扮くってくれた.

\section{筆者のレオロジー研究と回想}

筆者がレオロジーに関連する問題に着手したのは, FreundlichSchmidt-Lindau によるベントナイトについての論文を手にした 1932年ごろからであり，その矼究対象に日本産の粘土鈗物（酸性 白土，カオリン，モンモリロナイトまたはベントナイト）のサス ペンジョンを選んで上記諭文の内容と比較することを試みた，同 時に $\mathrm{V}_{2} \mathrm{O}_{5}$-ゾル， $\mathrm{Fe}_{2} \mathrm{O}_{3}$-ゾル，パラフィン・サスペンジョン(べ ンゼン中), 密ろう・サスペンジョン（エチルアルコール中）な どのコロイド系に扮ける流動特性, チキソロピー, ダイラタンシ 一,レオペクシーについての実験的理論的考察を試みた。 これら の研究は戦時中に及んだが，数年間の不如意の時期を経て，戦後 は日本の特産鉣物セリサイト・サスペンションについて（1953〜 60), 更に最近は液晶 (熱変性および溶媒変性) についてその流動 特性と構造との関係などについて研究を行って現在に至った。乙 かし，実験技術は当初から現在に至るまで単純で，時によっては 偶々新現象に出遇らこともあったが，とくに戦後に扔けるレオ口 ジーの理諭・実験の急速な進歩に追い付くためには少なからず困 難を感じたのである.

本文は諭説ではなく，回想であるから二，三の插話的余談を記 すことにしょう。酸性白土についての矿桀を初めた頃，市販の試 料は砂などの雑物が含まれていて実験に適しないので原産地とし て知られる新潟県（富山県との境に近い）糸魚川町（現在は市） に助手一人を伴って採集に出掛けた。この町を流れる川に沿ら丘 陵には粘上層の露頭が見られるところがある．地表またはそれに 近い浅い層の粘土は褐色または黄色を呈しており，その一部を蒸 留水汇懸濁させてリトマス試験紙を浸してみると青色が赤色に変 わる，その故にその粘土を“酸性白土”と呼んだのであろう。乙 かし，少しく掘り下げて1メートルほどの深さのところから採取 した粘土は青白色で軟らかく手のひらに糊のように粘着する。そ の懸濁液は中性またはアルカリ性を示す。数種の自然のサンプル を実験室に持ち帰って化学分析をした結果，この地域の粘土はア メリカ産のベントナイトに比較すると, 概してアルカリ分の含量 が少ないことが分かった．しかし，それを弱アルカリまたは食塩 水で処理すると, イオン交換によってベントナイトに近い性質の ものになり，チキソロピーの研密試料として適切なものとなるこ とが分かった。ところで一㐫採集を終えてから糸魚川の河口に行 って見た。そこには土手近くには芦が繁っているが海に向って巨 大な三角洲が張り出していた。芦の葉をかき分けながらその三角 洲の一端に足を踏み入れたところ，一見安静であった地盤がかな りの広さに互って緩やかに振動し初めた。更に歩を進めるとその 振動が増幅し，足元が砂地に吸い込まれるように感じた。それは 驚さであり，恐怖であった，筆者はこれが Reynolds の “quick sand”であると直観し，更に踏み込むことを止めて戻った。つい でにその砂地の少量を採取して帰り調べたところ，その試料の中 には砂のほかに若干量の粘土が含まれていることが分かった。そ の結果は Freundlich による quick sand の研究結果と一致し，そ の振動はチキントロピーに帰せられるものと理解した。この奇妙 な経験について筆者は新聞紙上に軽い記事を書いたことがある （“人をだます砂”朝日新聞，昭 $36 \cdot 8 \cdot 12)$ ，糸魚川付近では大 
雨の後や雪どけの時に崖崩れ，山津波が起こり易いことを聞いた が，その原因として，丘陵の粘土層の膨潤と外圧による軟化・流 動（チキソトロピー）の現象があるのではないか，という私見を 人に語ったこともある。それから紛 2 年後, 新潟県能生町で山崩 れが起こったことを知ったが，その時も新聞（朝日新聞，昭 38 ・ 3・22）にこの地方に堆積する粘土層——それは白土とよばれる ものを含んでいる—のチキソトロピーに関係があるのではない かと推論し，地層についてのレオロジ一的研究の必要性を説いた こうがある。しかし，筆者の提言が実際に容れられたかどらか， 知ることができなかった，火山国として日本の地層の研究は土木 工学や農学の立場からのみではなく, レオロジ一的基礎研究が必 要であるという筆者の見解は現在も変わらない，わが国では，と かくこのような地道なルーティンの研究が為政者にも学者にも歓 ばれない風習があるのは遺㗪である。

次の插話は筆者にとってむしろられしい思い出である. 昭和 17 (1942) 年, 東大理学部の鮫島実三郎教授の主催で膠質化学討諭 会が同学部化学教室講義室で行われた，そのとき，筆者は共同研 呪者・佐藤弘一氏との連名で,「膠質系に於ける可逆的現象と粒 子間力のポテンシャル曲線」の題目の講演をしたが, その際筆者 は $\mathrm{V}_{2} \mathrm{O}_{5}$-ゾルの流動複屈折, $\mathrm{Fe}_{2} \mathrm{O}_{3}$-ゾルの律動による可逆的凝結 ( 1 種のレオペクシ一)と共に, 筆者がベルリン当時の同僚 Zöllner 博士からもらってきた $\mathrm{Fe}_{2} \mathrm{O}_{3}$-ゾルのチキソトロピーの供覧実験 を行った．聴講者の中に当時な招学部学生であった中川鶴太郎, 神戸博太郎の諸君がいた一一諸君とはまだ面識がなかった一一こ とを後で知った，中川君の手記によると，この講演がこれらの諸 君のレオロジーへの関心を梁め, 日本におけるレオロジー䂺究の 開拓への道に誘う一つの動機となったらしい。な拈, Zöllner の $\mathrm{Fe}_{2} \mathrm{O}_{3}$-ゾルは現在も筆者の研栄室の棚の中に保存されているが, 半世紀の間に変質し, ゲルはゾルになって戻らない, しかし, 試 験管の上方に粘着した黑褐色の薄層はシラ一層の特性を示すこと が分かった，上述の筆者らの講演の内容はその実験も理諭も単純 なものではあったが，新しい知見であったと思う。しかし，それ は鮫島博士編集の「膠質化学論叢・第 1 輯, 1943」に寄稿された が，戦時中のことであり広く内外に知られることがなかった，や がて戦争は末期的状沉となり，筆者の研究も前進を阻まれるに至 った。もし戦中・戦後の混乱がなかったならば, 筆者のレオロジ 一研究もいくらか良い喿実を結てだであろうと残念に思う。

\section{日本におけるレオロジーの発展}

時は移って戦後になった。筆者の職場にも変化が起こったが 1949年ごろに手に入れた本Scott Blair：Introduction to Industrial Rheology (独訳本, 1940), 同著者：Survey of General and Applied Rheology (London, 1943) によって筆者はレオロジーな る新しい科学の分野についての概念を得た。 同時にその頃から駒 場の東大教養学部の化学教室あるいは隣接の東大理工学研兑所内 の研究室に扮いて神戸・中川・その他 2,3 の同士諸君と共にレ オロジーについての懇談会を持つことができた。やや゙て1951年度 の日本化学会・コロイド化学討諭会の企画を依頼されるに際して, 2 日間の中の 1 日をとくにレオロジーを討諭の題目とすることを 提案し, 神戸博士の援助の下に理工学政究所講堂に执いてそれを 実施した。初めての企画で多少の不安があったが，意外に多くの 諭文の寄与があり，とくに京大工学部の背尾教授を初めとする緎
維, ゴム, 塗料などの工業製品のレオロジー的問題に関する論文 が寄与され，極めて活発な討論と意見交換が行われた。ここに日 本のレオロジー磍の端緒が開かれた。1952年度からはレオロジ 一討論会は独立のものとして企画・開催されることになり，初め は日本化学会内にレオロジー委員会が設置されたが, やがて高分 子学会内にレオロジ一委員会が設立されるに至って (1955) 前者 は解消され, 更に材料試験協会 (後の材料学会) の中にもレオ口 ジー委員会が設置され，これら両委員会の合同企画によって年 1 回のレオロジー討論会が日本の各主要都市で開かれるようになっ た. 第 5 回討論会までの寄稿論文についてはその英文抄録を粗末 な紙のタイプ印刷として海外の主なレオロジー学会, レオロジー 研究グループ, 抢よび個人研究者に頒布したが, その後は材料学 会の機関誌の特集号に和文論文あるいは報告に英文抄録を付し， それを頒布するようになった。 そして1970年, 日本レオロジー学 会が設立されてからはその機関誌に扔いてすべて（ただし，生物 レオロジーは分離して1977年に日本生物レオロジー学会が誕生 した）が統一的沉処理されるに至ったのである.

一方, 海外でのレオロジー研究は前述の Bingham による提唱 以来, アメリカはもちろん, イギリスでもフランスでも, ドイッ でもオランダでもそれぞれの組織によって活動が行われたが, 1948年オランダで行われた粘性および塑性に関するシンポジウム をもって第 1 回国際レオロジー会議とすることが主要な参加者に よって丞認され，5年ごとに国際会議を各国で開催することが定 められた，第 2 回はイギリス・オックスフォードで開かれたが, そのとき日本から送った前記の英文抄録集が組織委員長 Scott Blair によって参加者に紹介され，日本のレオロジー研究の状沉 が認識された。また，非公式ながら組織された「国際レオロジ一 委員会」に日本代表として筆者が加えられるよ5になった。その 前後 Scott Blair と筆者との間に取り交わされた書簡集はレオ口 ジー発達实の一つのドキュメントであるかも知れない，第 4 回は 1958年西ドイツで開かれたが，その主催者 H.F. Müller から筆 者の出席を強く要請（日本学術会議会長宛）されたが，この国際 委員会が ICSUに属していないことや，招請状が時期的に急であ ったことなどから，筆者の出席は果たされず，偶々渡欧中の後藤 廉平教授（京大）扣よび森芳郎教授（東大）に参加してもらった。 第 4 回は1963年アメリカ・プロビデンスのブラウン大学で行われ たが，そのときは堀尾正雄教授 (京大), 岡小天教授（都立大） 活か少壮の研究者数名と共に筆者もそれに参加した。いわば初め ての日本のレオロジストのデモンストレーションであった.この 会議中に開かれた国際委員会において第 5 回会議を日本で開催す ることが提案され，筆者は堀尼教授の有力な援助によってそれを 受諾したのである。こうして1968年京都に执いて第 5 回レオロジ 一国際会議が開かれ，非常な好評を得たことは衆知のと括りであ る.この会議に打いての国際委員会に招いて, その組織をICSU の中に含めること, 委員会の構成, 秋員の選挙についての規約を 作ること, 会議の開催を 4 年ごとにすることなどが提案され, 承 認された，筆者は煀屁教授と共にこの会議の組織委員長の責任を 興たしたが，その機会に非公式国際委員会の日本代表の任を辞し， 一つの精神的荷重から解放された，それまで約20年間のいきさつ を顧みれば，筆者にとって奇しき因縁とも言ろべきものであった。 


\section{その後の余談と将来への希望}

それから間もなく，筆者は大学教授としての第二の定年を迎え 責任のあまり重くない立場になり，しかも戦前の矿究室（武蔵大 学内根津化学研究所）に戻ることになった．長らく研究者不在の ままに放任された場所を整理するのに約半年を要したが，また㸴 究室に残された機器・器具は既に老化し使用に堪えるものは僅か であったが，ともかく仕事場を得たことは幸いであった。資金も なく，人手もない状況で何が出来るか分からなかったが，か衫て から気掛りであった昔の残り仕事があってそれをいくらかでも解 決したいと考兵た。それは1934年に発表した「二次相の状態式と 表面層の構造」の論文の中で, 液晶または中間相と呼ばれた物質 の表面張力に扣ける異常性であり，筆者のこの諭文の前年に登表 されたWo. Ostwald の諭文で指摘された同様の物質の示する粘 性の異常性であった。これらの問題は液晶としての純物質が得ら れれば, 測定は比較的単純な方法で行われる—-表面張力につい てはその測定技術が大へんむずかしいことが算から分かったが 一と考えたので，その問題を取り上げることにした．幸いに他 大学の卒業研究委託生 $2 \sim 3$ 人を得たので, 彼らにルーティンの 実験をやってもらうことが出来た。偶々1971年のアメリカのゴー ドン・コンフェレンスが R.S. Porter 拈よび J.F. Johnson の主 催によって初めて液晶の問題を报った際に招かれて，とくに「表 面張力の異常性の考察」を話したところ，この古典的問題は未解 決で興味あるものであることが認知された。この問題（熱変性液 晶の表面張力）についての実験・理諭的研究は今な打十分な解決 に達していないが，A.C.S. コロイド・シンポジウムの 50年を記 念する“コロイド抢よび界面の科学”に関する国際会議 (1976年 サン・ファンに执いて）に扣いて，筆者として一応結佩的と思わ れる報告をした。 また, その間に興味は溶媒変性（ライロトロピ ック）液晶の相平衡・鋲造・物性に拡大され，とくにそれらにつ いてのレオロジー的研究を実施した。 それはP Porter 教嗳などに よってレオロジーに拈ける新しい問題として注目されるようにな った。 このように仕事を始めると，いくらでも次々に問題が出て くるが，年齢は逆行せずいよいよ限界に達するというのが最近の 所感である.この夏の終り( 8 月 27 日〜 9 月 1 日)アメリカ・サン ・ディエゴのカリフォルニア大学で行われる第 3 回国際生物レオ ロジー会議に招かれて合同セッションで譵演することになったが， 演題は "From Colloid Science to Biorheology-A Historical Reminiscence”である。筆者ももはや国際的にも希少価值の存在 となったようだ。これからは若い有為な研笔者の生長を祈るの夕 である.

本年 5 月19日, 日本レオロジ一学会の年次総会が京大楽友会館 で開かれた際に, 同学会理事会に执いて筆者を同学会の名誉会員 に推挙する決議が行われた，筆者はその総会に出席し，会長小野 木重治教授からその証書を手渡される光栄に浴した。このことは 筆者のレオロジストとしての最大の記念であり, 感謝である.
この総会後のパーティーに招いて筆者は感謝の挨拶と共に短い回 想を語ったのであったが, 帰京後間もなく, 同レオロジー学会・ 編集委員長・倉田道美教授から同学会誌に何か寄稿するようにと の依頼を受けた。いろいろ考えたが，総説と呼ぶに相応しい記事 を書くまでの準備はないので, 結局上記のような雑文を緅るにと どまった，顧みれば，第10回レオロジ一討論会が上田の信州大学 ・䋐維工学部で行われたとき, 筆者は「わが国に抢けるレオロジ 一研究10年の歩み」と題する特別講演を行い, その中で第10回衣 でのレオロジー討論会で発表された諭文に示された研究問題・研 兑者についての統計を基にして将来への展望を試みた。わが国の レオロジー討論会は間もなく30回を迎えようとしている。る筆 者になお余命があるならば，その機会にその後の進歩の情勢を加 えて統計・分析を試み，それが出来れば改めて本誌の総説として 奇稿したいと思5。今回は日本レオロジ一学会の最初の名誉会員 として推挙されたことに対する感謝のしるしとしてこのような回 想記を寄稿する次第である。もっとも回想記といっても個人の断 片的な思い出を書いたものであって, 日本あるいは海外のレオロ ジ一歴史を忠実追うたものではないことは読者の直ち気付か れる通りである。その意味から引用文献も主な著書・報告の類に 限って下記する次第である。読者の諒承を乞いたい。

$(20 \cdot 07 \cdot 1978)$

\section{主な引用文献}

E.C. Bingham, Fluidity and Plasticity, New York (1922).

Wo. Ostwald, Die Welt der vernachlässigten Dimensionen, Dresden u. Leipzig (1927).

H. Freundlich, Kapillarchemie I, II, Leipzig (1930 32).

H. Freundlich, Thixotropy, Paris (1935).

H.R. Kruyt, Colloid Science I, II, Amsterdam (1949 52).

G.W. Scott Blair (H. Kauffmann), Einführung in die Technische Fliesskunde, Dresden u. Leipzig (1940).

G.W. Scott Blair, Survey of General and Applied Rheology, London (1943).

Deutsche Rheologische Gesellschaft, Herbert-Freundich-Gedächtnis-Kongress, Berlin (1954).

The Academy of Science, Reports on Viscosity and Plasticity, Amsterdam (1939 1948).

V.G.W. Harrison (ed.), Proceedings of the Second International Congress on Rheology, London (1954).

E.H. Lee-A.L. Copley, Proceedings of the Fourth International Congress on Rheology, 1 4, New York (1965).

S. Onogi, Proceedings of the Fifth International Congress on Rheology, 1〜4, Tokyo (1969).

玉蟲文一先生受賞記念会, 玉蟲博士 受賞記念論集 (非売品), 東京，1976．〔この中に筆者のレオロジーに関する諭文リス トがある」。 